\title{
Effect of arbuscular mycorrhizal fungi (Glomus spp.) on growth and arsenic uptake of vetiver grass (Chrysopogon zizanioides L.) from contaminated soil and water systems
}

\author{
A.G. Caporale ${ }^{1 *}$, D. Sarkar ${ }^{2}$, R. Datta ${ }^{3}$, P. Punamiya ${ }^{2}$, and A. Violante ${ }^{1}$ \\ ${ }^{1}$ Dipartimento di Agraria, Università degli Studi di Napoli Federico II, Portici (NA), Italy \\ * Corresponding author: ag.caporale@unina.it \\ ${ }^{2}$ Department of Earth and Environmental Studies, Montclair State University, Montclair, NJ, USA \\ ${ }^{3}$ Biological Sciences Department, Michigan Technological University, Houghton, MI, USA
}

\begin{abstract}
Phytoremediation technology is emerging as a promising environment-friendly method for large-scale cleanup of arsenic (As) contaminated water and soil. In this study we investigated the effect of arbuscular mycorrhizal fungi (AMF - Glomus spp.) on the growth of the vetiver grass (Chrysopogon zizanioides L.) and its As uptake from contaminated hydroponic and soil systems.

An ameliorative effect of the AMF inoculation in enhancing plants growth was found, mainly by stimulating the development of their root system. In addition, AMF-inoculated plants also took up more As from both contaminated systems compared to non-inoculated plants, although the differences were not always statistically significant $(p$ $<0.05)$. Nevertheless, more efficient As uptake by vetiver grass from contaminated hydroponic solutions than spiked soils was observed, essentially because of the higher phytoavailability in the former contaminated system. Furthermore, plants grown hydroponically also translocated higher amounts of As from their roots to shoots. Therefore, the findings of this study reveals that the use of vetiver grass technology in conjunction with AMF would be more appropriate to decontaminate As-contaminated water than soils.
\end{abstract}

Keywords: Vetiver grass, arsenic, arbuscular mycorrhizal fungi, phytoremediation, water, soil 


\section{Introduction}

Arsenic (As) contamination of the environment is a global concern, which poses potential environmental and human health risks. Various anthropogenic activities such the use of arsenical herbicides and pesticides, mining, waste disposal and atmospheric deposition result in As contamination of water and soil (Mohan and Pittman, 2007).

Arsenic remediation is largely done using conventional technologies, because of their relative insensitivity to the heterogeneity of the contaminated systems. Moreover, these technologies are applicable over a wide range of oxygen, $\mathrm{pH}$, pressure, temperature, and osmotic potentials (Mohan et al. 2007). Disadvantages of the conventional techniques include high expense and time requirements, potential hazard to workers and production of secondary wastes that may not be environmentally friendly. Out of these, cost is the major reason for the current interest in development of alternative remediation technologies, such as phytoremediation (Bhattacharya et al. 2002).

Phytoremediation technology is emerging as a promising, environment-friendly method for large-scale cleanup of As-contaminated water and soil (Wong et al., 2007). Phytoremediation is a solar-driven, inexpensive technology; and hence might be suitable for cleaning up widespread As contamination (Srivastava et al., 2011). For successful phytoremediation, it is crucial to select an appropriate pioneer plant species for site reclamation and ensure a selfsustainable vegetative cover.

Vetiver grass (Chrysopogon zizanioides L. Roberty), a native grass of India is capable of tolerating harsh environmental conditions such as drought, salinity and metal (loid)s contamination (Pang et al., 2003). Vetiver is a fast-growing, perennial plant. Owing to its morphological, physiological and ecological characteristics (Dalton et al., 1996; Truong, 2000) and its tolerance to a wide range of abiotic stress, such as High background As in soil (Chen et al., 2000; Truong, 2000), interest in this grass has increased in the last decade. It seems that vetiver grass will become one of the main the biological systems for soil and water conservation in the $21^{\text {st }}$ century (Truong, 2000). A greenhouse study on the phytoremediation potential of vetiver grass in different Ascontaminated soils was recently carried out by Datta et al. (2011), who found a significant As uptake by vetiver grass, which was strongly affected by the soil physico-chemical properties.

In addition to soil properties, As uptake by fastgrowing plants such as vetiver grass can be also influenced by soil microorganisms closely associated with plant roots to form a rhizosphere community, such as the arbuscular mycorrhizal fungi (AMF) (Smith and Read, 1998; Gaur and Adholeya, 2004; Pigna et al., 2014). These fungi have been largely studied because of their ability to enhance plant wellness under abiotic stress (e.g., As-contamination) (Leyval and Joner, 2001; Cozzolino et al., 2010), although their effectiveness depends on different factors, such as plant species, fungal species/ecotypes and soil chemistry (Li and Feng, 2001). Some literature is available on the role of mycorrhizae in As uptake by Chinese Brake fern (Pteris vittata ), a well known As hyperaccumulator (Liu et al., 2005; Leung et al., 2006). However, 
there is a lack of detailed investigations on the response of vetiver grass to AMF inoculation when grown in As-contaminated environments. Therefore, the present study was carried out in order to investigate the effect of AMF inoculation on the growth and As uptake of vetiver grass (Chrysopogon zizanioides L.) from contaminated hydroponic and soil systems.

\section{Materials and Methods}

\subsection{Experimental design}

This study consisted of vetiver grass grown both hydroponically in half strength Hoagland solutions spiked with As (experiment I) and in plastic columns containing As-spiked soils (experiment II), inside a glasshouse with controlled light regimen, temperature (23 to 28 ${ }^{\circ} \mathrm{C}$ ), and humidity (55 to $62 \%$ ). Vetiver plants were bought from Florida Farms and Nurseries, St. Cloud, FL. They were initially allowed to acclimatize for 2 weeks in plastic pots, $30 \mathrm{~cm}$ deep, containing tap water. Subsequently, they were transferred into two containers filled with half strength Hoagland solution consisting of $0.0676 \mathrm{~g}$ of $\mathrm{KH}_{2} \mathrm{PO}_{4}, 0.253 \mathrm{~g}$ of $\mathrm{KNO}_{3}, 0.59 \mathrm{~g}$ of $\mathrm{Ca}\left(\mathrm{NO}_{3}\right)_{2} \cdot 4 \mathrm{H}_{2} \mathrm{O}$, and $0.20 \mathrm{~g}$ of $\mathrm{MgCl}_{2} \cdot 6 \mathrm{H}_{2} \mathrm{O}$ per liter. In one of these containers a plentiful source of AMF for root plants was also provided by disposing, on its bottom, some Petri plates containing nutrient agar medium, in which AMF spores were allowed to grow for 2 days at 35 ${ }^{\circ} \mathrm{C}$ in an incubation chamber. Vetiver seedlings were settled on the agar plates, with the roots touching the AMF-containing agar and allowed to grow into this container for 4 weeks. The AMF spores were purchased from Garden-Ville, Austin, TX, USA. The product was composed of 3 species: Glomus intraradices, G. mosseae and $G$. aggregatum, blended so that the 3 species are included in equal proportion $(20,000$ propagules of each). The carrier was $90 \%$ of Montmorillonite clay and $10 \%$ of Quartz, a porous material where the mycorrhizae can impregnate the small spaces. A separate set of vetiver were also grown for 4 weeks on nutrient agar without any AMF in Hoagland's solution to provide a control set with general microbial population free of Glomus spp. spores.

After four weeks in contact with the AMF, 3 $\mathrm{cm}$ of root samples were collected to define the rate of inoculation. Root samples were stained using aniline blue dye according to Hebert et al. (1999). A mycorrhizal inoculum percentage (MIP) bioassay was carried out according to Sylvia (1994). The total number of visible cells and the number of infected cells were counted. The rate of infection (\%) was obtained by dividing the inoculated cells by the total cells and was to be, on average, $58 \%$. Therefore, an acceptable number of vetiver roots was found to be colonized by the AMF inoculum containing Glomus spp.

\subsubsection{Experiment I: hydroponic study}

After successful colonization of vetiver roots, AMF-inoculated $(\mathrm{M}+)$ and AMF-non-inoculated (M-) plants were grown hydroponically for 4 weeks in As-contaminated half strength Hoagland solution. The experimental design consisted of a completely randomized factorial block design; treatments consisted of 4 rates of As in half strength Hoagland solution $[0(0 \mu \mathrm{M})$, $150(150 \mu \mathrm{M}), 300(300 \mu \mathrm{M})$ and $500(500 \mu \mathrm{M})$ micromoles of As per liter of solution], using $\mathrm{M}+$ or M- plants. Sodium hydrogenarsenate 
heptahydrate $\left(\mathrm{Na}_{2} \mathrm{AsO}_{4} \cdot 7 \mathrm{H}_{2} \mathrm{O}\right)$, purchased from Sigma-Aldrich, USA, was used as the As source. Each treatment had 3 replicates.

\subsubsection{Experiment II: greenhouse column study}

In addition to the hydroponic experiment, AMFinoculated $(\mathrm{M}+)$ and AMF-non-inoculated (M-) vetiver plants were also transplanted into plastic columns containing As-spiked soils and allowed to grow for 4 weeks. The bottom of each column was filled with play sand in order to facilitate water flux into the soil during leaching operations (leachate samples were collected and analyzed each week). The experimental design consisted of a completely randomized factorial block design; treatments consisted of 4 rates of As into soil [0 (0 mg kg-1), $12.5\left(12.5 \mathrm{mg} \mathrm{kg}^{-1}\right), 25$ (25 mg $\left.\mathrm{kg}^{-1}\right)$ and $50\left(50 \mathrm{mg} \mathrm{kg}{ }^{-1}\right)$ milligrams of As per kilogram of soil], using $\mathrm{M}+$ or $\mathrm{M}$ - plants.

The soil was collected from the Pineland Field Station of Rutgers, the State University of New Jersey, Camden, NJ, USA and characterized using standard protocols before spiking with As. Its principal physical and chemical properties are reported in Table 1. Briefly, the soil of this area primarily consist of unconsolidated deposits of sand with some clay, silt and gravel. The soil was a sandy podsol of the Lakehurst and Woodmansie soil series, which is acidic, with low organic matter content, and very low fertility.

Sodium hydrogenarsenate heptahydrate $\left(\mathrm{Na}_{2} \mathrm{AsO}_{4}\right.$ - $7 \mathrm{H}_{2} \mathrm{O}$ ), purchased from Sigma-Aldrich, USA, was used as the As source, in order to spike the Pineland soil at concentrations of $0,12.5,25$ and
50 milligrams of As per kilograms of dry soil. Each treatment had 3 replicates.

\subsubsection{Harvest and sample collection}

The vetiver plants of both Experiments I and II were harvested and then separated into roots and shoots (stems plus leaves) by a sharp blade. Fresh tissues were weighted, washed with tap water, rinsed twice with deionized water then dried to a constant weight in the oven for two days at $70{ }^{\circ} \mathrm{C}$. The dried tissues were also weighed and then finely ground before analyses.

Table 1. Physical and chemical properties of the As-uncontaminated Pineland soil

\begin{tabular}{lc}
\hline Soil Properties & Amount \\
\hline Sand $\left(\mathrm{g} \mathrm{kg}^{-1}\right)$ & $615 \pm 32$ \\
Silt $\left(\mathrm{g} \mathrm{kg}^{-1}\right)$ & $309 \pm 17$ \\
Clay $\left(\mathrm{g} \mathrm{kg}^{-1}\right)$ & $76 \pm 5$ \\
Soil $\mathrm{pH}\left(\right.$ in $\left.\mathrm{H}_{2} 0\right)$ & $6.13 \pm 0.21$ \\
Organic Carbon $\left(\mathrm{g} \mathrm{kg}^{-1}\right)$ & $7.24 \pm 0.19$ \\
CEC $\left({\left.\mathrm{mequiv} 100 \mathrm{~g}^{-1}\right)}\right.$ & $13.83 \pm 0.25$ \\
Total Al $\left(\mathrm{g} \mathrm{kg}^{-1}\right)$ & $4.35 \pm 0.16$ \\
Extractable Al $\left(\mathrm{g} \mathrm{kg}^{-1}\right)$ & $1.66 \pm 0.07$ \\
Total Fe $\left(\mathrm{g} \mathrm{kg}^{-1}\right)$ & $3.19 \pm 0.12$ \\
Extractable Fe $\left(\mathrm{g} \mathrm{kg}^{-1}\right)$ & $0.86 \pm 0.05$ \\
Total N $\left(\mathrm{g} \mathrm{kg}^{-1}\right)$ & $0.68 \pm 0.03$ \\
Available P $\left(\mathrm{mg} \mathrm{P}_{2} \mathrm{O}_{5} \mathrm{~kg}^{-1}\right)$ & $16.4 \pm 0.3$ \\
Total As $\left(\mathrm{mg} \mathrm{kg}^{-1}\right)$ & $0.706 \pm 0.035$ \\
\hline
\end{tabular}


Table 2. The root, shoot and total biomass of vetiver grass (Chrysopogon zizanioides L.) grown in As-contaminated hydroponic solutions at harvest time

\begin{tabular}{cccc}
\hline Treatment & Roots & Shoots & Total biomass \\
\cline { 2 - 4 } & & $(\mathbf{g})$ & \\
\hline As 0 M + & $4.53 \pm 0.25 \mathrm{a}$ & $9.63 \pm 0.67 \mathrm{a}$ & $14.16 \pm 0.91 \mathrm{a}$ \\
As 0 M - & $4.29 \pm 0.29 \mathrm{ab}$ & $9.34 \pm 0.75 \mathrm{ab}$ & $13.63 \pm 1.02 \mathrm{ab}$ \\
& $(5.1)^{*}$ & $(3.0)^{*}$ & $(3.7)^{*}$ \\
As 150 M + & $4.64 \pm 0.43 \mathrm{a}$ & $9.19 \pm 0.80 \mathrm{ab}$ & $13.84 \pm 0.68 \mathrm{a}$ \\
As 150 M - & $4.71 \pm 0.54 \mathrm{a}$ & $8.58 \pm 0.64 \mathrm{abc}$ & $13.29 \pm 0.16 \mathrm{ab}$ \\
& $(-1.4)^{*}$ & $(6.7)^{*}$ & $(4.0)^{*}$ \\
As 300 M + & $4.49 \pm 0.13 \mathrm{a}$ & $7.65 \pm 0.89 \mathrm{abc}$ & $12.14 \pm 0.89 \mathrm{abc}$ \\
As 300 M - & $3.65 \pm 0.52 \mathrm{abc}$ & $7.49 \pm 0.98 \mathrm{bc}$ & $11.14 \pm 1.48 \mathrm{bc}$ \\
& $(18.7)^{*}$ & $(2.1)^{*}$ & $(8.2)^{*}$ \\
As 500 M + & $3.35 \pm 0.35 \mathrm{bc}$ & $6.93 \pm 0.59 \mathrm{c}$ & $10.28 \pm 0.72 \mathrm{c}$ \\
As 500 M - & $3.05 \pm 0.44 \mathrm{c}$ & $6.99 \pm 0.53 \mathrm{c}$ & $10.04 \pm 0.92 \mathrm{c}$ \\
& $(9.0)^{*}$ & $(-0.8)^{*}$ & $(2.3)^{*}$ \\
As level & $p<0.0001$ & $p<0.0001$ & $p<0.0001$ \\
AMF applic. & $p=0.0577$ & $p=0.4188$ & $p=0.1415$ \\
Interaction & $p=0.2782$ & $p=0.8825$ & $p=0.9110$ \\
\hline
\end{tabular}

Data are expressed as mean values $\pm \mathrm{SD}(\mathrm{n}=3)$ and have been analyzed by two-way analysis of variance. Mean values followed by the same letter within columns are not significantly different by Tukey's test at the $5 \%$ level. Total biomass is the sum of the root and shoot biomass. The As 0, As 150, As 300 and As 500 refer to As concentrations of $0,150,300$ and $500 \mu \mathrm{M} \mathrm{L}^{-1}$, while the $\mathrm{M}+$ and $\mathrm{M}$ - refer to the presence or absence of AMF. * The relative change (\%) in root, shoot and total biomass was calculated by dividing the $\mathrm{M}$ - treatment by the $\mathrm{M}+$ treatment for each As level (e.g., reduction in root biomass of As $0 \mathrm{M}$ - treatment $(100-(4.29 / 4.53 \mathrm{x}$ $100)=5.1 \%)$. 


\subsection{Analytical procedures}

\subsubsection{Chlorophyll A and B concentrations in} vetiver leaves

One gram of leaf tissue was harvested from each vetiver plant (Experiments I and II) and the tissue was shaken with $5 \mathrm{~mL}$ of acetone/water $[80 / 20 \%,(\mathrm{v} / \mathrm{v})]$ mixture for $1 \mathrm{~h}$ on a reciprocal shaker at $200 \mathrm{rpm}$. The extract was filtered through a $0.22 \mu \mathrm{m}$ filter. The extraction was repeated one more time using the residual tissue, and the extract was filtered. The filtrates from the two extractions were combined, and the final volume was made up to $10 \mathrm{~mL}$ with deionized water. All extracts were assayed using a Bio-Rad Benchmark Microplate reader. Chlorophyll A and $\mathrm{B}$ concentrations ( $\mathrm{mg} \mathrm{kg}^{-1}$ dry weight) were calculated by measuring the absorbance of the filtrate at $663 \mathrm{~nm}$ (D 663) and $645 \mathrm{~nm}$ (D 645) using the formula of Arnon (1949).

\subsubsection{Arsenic determination}

Half gram of dried tissues of each vetiver plant (Experiments I and II) and As-spiked soils were weighed into PTFE vessels and digested in $15 \mathrm{~mL}$ of $\mathrm{HNO}_{3}(65 \%)$, using a microwave Mars system (CEM Corporation, Matthews, $\mathrm{NC}$, USA); the digested solutions were filtered through $0.45 \mu \mathrm{m}$ filters and then diluted to 50 $\mathrm{mL}$ with deionized water. Total As concentration in the As-contaminated hydroponic solutions, leachate samples, and filtrates of dried vetiver tissues and As-spiked soils were determined using a Perkin Elmer Elan-9000 inductively coupled plasma mass spectrometry (ICP-MS).
The As detection limit of this method was 1.55 . $10^{-3} \mathrm{mg} \mathrm{L}^{-1}$.

\subsection{Statistical analysis}

Mean values were compared by ANOVA and the Tukey's test at the significance level $p<0.05$. Data on plant biomass, As concentration and content were treated by two-way ANOVA with factors As and AMF, and tested for normality using the Shapiro-Wilk test.

\section{Results and Discussion}

\subsection{Plant growth and As toxicity}

The growth of the vetiver plants (i.e., dry root and shoot weights) was markedly affected by the As treatments $(p<0.005)$, in both Experiments I and II (Tables 2 and 3). On the contrary, the AMF inoculation influenced significantly ( $p$ $<0.001$ ) only the growth of the vetiver plants of the Experiment II, particularly, the root dry weight.

Increasing the concentration of As in the hydroponic solutions and As-spiked soils markedly decreased the biomass of the vetiver plants, indicating the phytotoxic effect of As (Tables 2 and 3). These results are in agreement with Datta et al. (2011) and Truong (2000), who reported vetiver growth in soils moderately contaminated by As, determining a significant decrease of vetiver biomass with increasing As concentration in the soil.

In our study, the most severe toxic effect of As was found in the Experiment I; in fact, vetiver plants grown in the most As-contaminated hydroponic solution $(500 \mu \mathrm{M})$ and As-spiked soil (50 $\mathrm{mg} \mathrm{kg}^{-1}$ ) produced, on average, a total 
biomass $27 \%$ and $17 \%$, respectively, lower than that produced by control plants in the absence of As. The vetiver plants exposed to the higher As levels (especially those of Experiment I) showed some typical phytotoxicity symptoms, such as yellowing and some necrosis at the tips; however, all the plants survived the study. Certainly, the full availability of the As in the contaminated hydroponic solutions exposed the vetiver plants to a greater abiotic stress, which also resulted in a lower development of the root system than that of the plants grown in the Asspiked soils.

The plants inculated plants produced higher biomass compared to the non-inoculated plants in both Experiments I and II, however, it was statistically significant $(p<0.001)$ only in the Experiment II (Tables 2 and 3). In this latter experiment, the total dry weights of the AMFinoculated vetiver plants were $8.9 \%$ (As $0 \mathrm{mg}$ $\left.\mathrm{kg}^{-1}\right), 18.3 \%$ (12.5 $\left.\mathrm{mg} \mathrm{kg}^{-1}\right), 5.1 \%\left(25 \mathrm{mg} \mathrm{kg}^{-1}\right)$ and $14.7 \%\left(50 \mathrm{mg} \mathrm{kg}^{-1}\right)$ higher than those of the non-inoculated plants. The positive effect of the AMF inoculation on the growth of the vetiver plants in Experiment II was essentially due to the higher development of their root system into the As-spiked soils. Recent studies on non-food (Chinese Brake fern) (Liu et al., 2005) and food (lettuce) (Cozzolino et al., 2010) plants have shown that the inoculation with AMF allows a better tolerance of plants to high concentrations of As in the contaminated soils, by producing a greater plant biomass and improving phosphorus status in plant tissues.

In contrast, the total dry weights of the AMFinoculated vetiver plants grown hydroponically (Experiment I) were only 3.7\% (As $0 \mu \mathrm{M}$ ), 4.0\%
$(150 \mu \mathrm{M}), 8.2 \%(300 \mu \mathrm{M})$ and $2.3 \%(500 \mu \mathrm{M})$ higher than those of the non-inoculated plants; in addition, we also found a negligible stimulatory effect of nutrient agar on vetiver growth (data not shown), by growing plants on a nutrient agar with general microbial population free of Glomus spp. spores.

\subsection{Chlorophyll $A$ and $B$ concentrations in the vetiver leaves}

The chlorophyll A and B concentrations in the vetiver leaves decreased significantly $(p<0.001)$ with increasing As level in both contaminated hydroponic solutions (Experiment I) (Figure 1A) and spiked soils (Experiment II) (Figure 1B). The accumulation of As in the leaf biomass has been demonstrated to reduce the photosynthetic rate (Marques and Anderson, 1986).

The inoculation of vetiver with Glomus spp. raised significantly the amount of chlorophylls $\mathrm{A}$ and $\mathrm{B}$ in the leaf biomass of plants grown hydroponically $(p<0.001)$; in particular, the leaves of the $\mathrm{M}+$ vetiver plants grown in the $150 \mu \mathrm{M}$ and $500 \mu \mathrm{M}$ As-contaminated hydroponic solutions exhibited chlorophyll A and B concentrations of $28.3 \%$ and $40.3 \%$, respectively, higher than those determined in the leaves of the $\mathrm{M}$ - plants (Figure 1A). However, the beneficial effect of the AMF inoculation on the amount of chlorophylls A and $B$ in the vetiver leaves was not statistically significant in the Experiment II (Figure 1B). Higher presence of chlorophylls A and B in the leaves of AMF-inoculated vetiver plants were also found by Punamiya et al. (2010), 
Table 3. The root, shoot and total biomass of vetiver grass (Chrysopogon zizanioides L.) grown in As-spiked soils at harvest time.

\begin{tabular}{|c|c|c|c|}
\hline \multirow[t]{2}{*}{ Treatment } & Roots & Shoots & Total biomass \\
\hline & \multicolumn{3}{|c|}{ (g) } \\
\hline As 0 M + & $9.47 \pm 0.80 \mathrm{a}$ & $10.22 \pm 0.72 \mathrm{a}$ & $19.68 \pm 0.09 \mathrm{a}$ \\
\hline As 0 M - & $\begin{array}{c}6.92 \pm 0.65 \mathrm{bc} \\
(26.9)^{*}\end{array}$ & $\begin{array}{c}11.02 \pm 0.57 \mathrm{a} \\
(-7.9)^{*}\end{array}$ & $\begin{array}{c}17.94 \pm 1.22 \mathrm{abc} \\
(8.9)^{*}\end{array}$ \\
\hline As $12.5 \mathrm{M}+$ & $8.40 \pm 0.18 \mathrm{ab}$ & $10.17 \pm 0.95 \mathrm{a}$ & $18.58 \pm 0.77 \mathrm{ab}$ \\
\hline As $12.5 \mathrm{M}-$ & $\begin{array}{c}6.03 \pm 0.45 \mathrm{c} \\
(28.2)^{*}\end{array}$ & $\begin{array}{c}9.14 \pm 0.66 \mathrm{a} \\
(10.2)^{*}\end{array}$ & $\begin{array}{l}15.17 \pm 1.10 \mathrm{~cd} \\
(18.3)^{*}\end{array}$ \\
\hline As $25 \mathrm{M}+$ & $5.38 \pm 0.14 \mathrm{c}$ & $11.32 \pm 0.15 \mathrm{a}$ & $16.70 \pm 0.02 \mathrm{abcd}$ \\
\hline As 25 M - & $\begin{array}{c}5.27 \pm 0.34 \mathrm{c} \\
(2.1)^{*}\end{array}$ & $\begin{array}{c}10.58 \pm 0.45 \mathrm{a} \\
(6.5)^{*}\end{array}$ & $\begin{array}{c}15.85 \pm 0.11 \mathrm{bcd} \\
(5.1)^{*}\end{array}$ \\
\hline As $50 \mathrm{M}+$ & $6.27 \pm 0.45 \mathrm{c}$ & $10.49 \pm 0.83 \mathrm{a}$ & $16.76 \pm 0.38 \mathrm{abcd}$ \\
\hline As 50 M - & $\begin{array}{c}5.07 \pm 0.49 \mathrm{c} \\
(19.2)^{*}\end{array}$ & $\begin{array}{c}9.24 \pm 0.92 \mathrm{a} \\
(12.0)^{*}\end{array}$ & $\begin{array}{l}14.30 \pm 1.41 \mathrm{~d} \\
\quad(14.7)^{*}\end{array}$ \\
\hline As level & $p<0.0001$ & $p=0.0916$ & $p<0.005$ \\
\hline AMF applic. & $p<0.0005$ & $p=0.1515$ & $p<0.001$ \\
\hline Interaction & $p<0.05$ & $p=0.2317$ & $p=0.2379$ \\
\hline
\end{tabular}

Data are expressed as mean values $\pm \mathrm{SD}(\mathrm{n}=3)$ and have been analyzed by two-way analysis of variance. Mean values followed by the same letter within columns are not significantly different by Tukey's test at the $5 \%$ level. Total biomass is the sum of the root and shoot biomass. The As 0 , As 12.5, As 25 and As 50 refer to As concentrations of $0,12.5,25$ and $50 \mathrm{mg} \mathrm{kg}^{-1}$, while the $\mathrm{M}+$ and $\mathrm{M}$ - refer to the presence or absence of AMF.

* The relative change (\%) in root, shoot and total biomass was calculated by dividing the $\mathrm{M}$ - treatment by the $\mathrm{M}+$ treatment for each As level (e.g., reduction in root biomass of As $0 \mathrm{M}$ - treatment (100 - (6.92/9.47 x 100) $=26.9 \%$ ). 

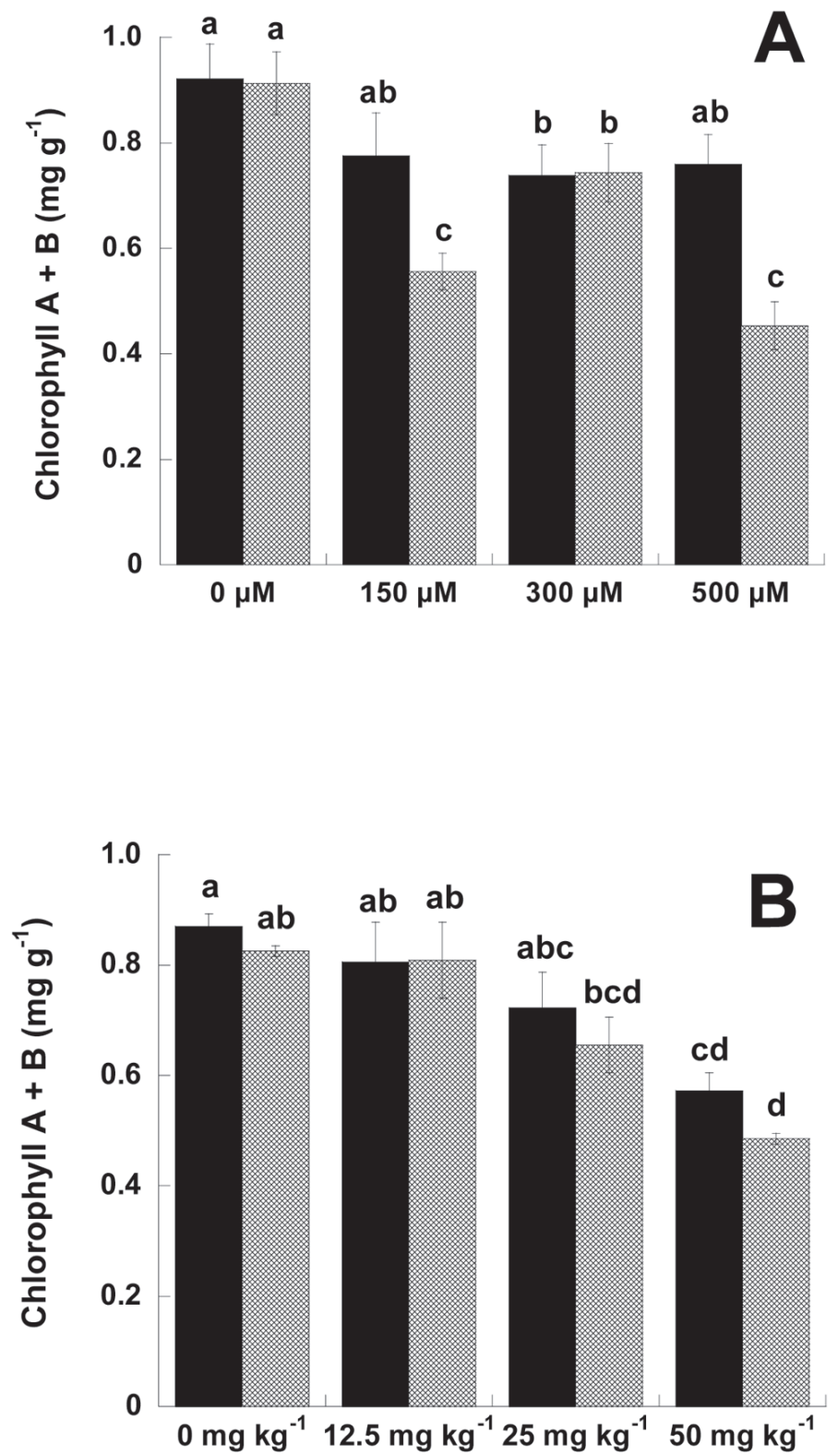

Figure 1. The concentration $\left(\mathrm{mg} \mathrm{g}^{-1)}\right.$ of chlorophyll A and B in the leaves of Vetiver grass (Chrysopogon zizanioides L.) grown in As-contaminated hydroponic (A) and soil (B) systems. Black bars refer to the plants inoculated with arbuscular mycorrhizal fungi (AMF), while grid bars refer to the non-inoculated plants. Data are expressed as mean values $\pm \mathrm{SD}(\mathrm{n}=3)$ and have been analyzed by Tukey's test at the $5 \%$ level (letters above bars). 


\subsection{Arsenic concentration and content in vetiver tissues}

Arsenic concentration $\left(\mathrm{mg} \mathrm{kg}^{-1}\right)$ and content (mg plant $\left.^{-1}\right)$ in the roots and shoots of vetiver grass markedly increased $(p<0.0001)$ with increasing As level in both contaminated hydroponic solutions (Experiment I) (Table 4) and spiked soils (Experiment II) (Table 5). These results confirm the earlier reports that vetiver grass can successfully survive in As-contaminated systems, showing a good capability of tolerating high levels of As in its tissues (Datta et al., 2011; Truong, 2000). As expected, vetiver plants grown hydroponically showed much higher As concentration and content than those of the plants grown in the soil (Tables 4 and 5), indicating an easier and efficient As uptake by vetiver grass from hydroponic system, in which As is completely phyto available.

Although the As concentration in the roots of vetiver plants grown hydroponically (Experiment I) was tendentially higher than shoots, most of the As taken up from the contaminated hydroponic solutions was translocated and accumulated in the shoots, as shown in Table 4, which was in part due to the larger shoot biomass compared to the roots.

On the contrary, the most of the As taken up from the As-spiked soils (Experiment II) was accumulated in the root system. Hence, a low translocation of As from roots to shoots of vetiver grass occurred when the plants were grown in soil. This behavior is similar to that reported by Datta et al. (2011), studying As uptake by vetiver grass from contaminated soils. A higher translocation of As from roots to shoots of plants is certainly desirable for successful phytoremediation of As-contaminated soils, in which only the aboveground plant biomass is usually harvested and removed for disposal.

The As uptake by vetiver plants was not significantly affected by the inoculation with commercial AMF inoculum containing Glomus spp., in both Experiment I and II (Tables 4 and 5). Significant differences $(p<0.05)$ between $\mathrm{AMF}$ and non-inoculated vetiver plants were just found in the roots of the plants in Experiment I (Table 4). The effect of AMF inoculation on plant uptake of metal(loid)s is not clear (Leyval et al., 1997). In AMF-inoculated plants, mycorrhizal phosphate transporters are activated (Rausch et al., 2001) and loss of function of the direct uptake pathway in colonized roots by AMF can apparently be complete (Smith et al., 2003). The suppression of activity of high-affinity phosphate transporters in roots might also ameliorate As tolerance (Gonzalez-Chavez et al., 2002). Moreover, by enhancing phosphorus status of the host plant, AMF usually promotes plant growth and consequently dilutes As in plant tissues (Liu et al., 2005; Dong et al., 2008). On the other hand, it has been suggested that AMF-inoculated hyperaccumulator plants (Chinese Brake fern) enhanced their As uptake from contaminated soils, indicating an ameliorative effect of AMF on the phytoremediation of As-contaminated soils (Liu et al., 2005; Leung et al., 2006).

\subsection{Arsenic concentration in the contaminated hydroponic solutions and soils}

Arsenic concentration in the contaminated hydroponic solutions $(\mu \mathrm{M})$ and soils $\left(\mathrm{mg} \mathrm{kg}^{-1}\right)$ at harvest time of vetiver grass is reported in Figure 2. Although lower final As concentrations were found in the hydroponic solutions of the AMF-inoculated vetiver plants than those of 
Table 4. Arsenic concentration ( $\mathrm{mg} \mathrm{kg}^{-1)}$ and content $\left(\mathrm{mg} \mathrm{plant}^{-1}\right)$ in the roots and shoots of vetiver grass (Chrysopogon zizanioides L.) grown in As-contaminated hydroponic solutions.

\begin{tabular}{|c|c|c|c|c|c|c|}
\hline \multirow{3}{*}{ Treatment } & \multicolumn{2}{|c|}{ As concentration in plant tissues } & \multicolumn{3}{|c|}{ As content in plant tissues } & \multirow{3}{*}{$\begin{array}{c}\text { As content in } \\
\text { the shoots } \\
(\%)\end{array}$} \\
\hline & Roots & Shoots & Roots & Shoots & Total biomass & \\
\hline & \multicolumn{2}{|c|}{$\left(\mathrm{mg} \mathrm{kg}^{-1}\right)$} & \multicolumn{3}{|c|}{$\left(m g\right.$ plant $\left.{ }^{-1}\right)$} & \\
\hline As 0 M + & $0.45 \pm 0.03 \mathrm{~d}$ & $0.16 \pm 0.02 \mathrm{~d}$ & $0.0043 \pm 0.0006 \mathrm{~d}$ & $0.0016 \pm 0.0001 \mathrm{e}$ & $0.0059 \pm 0.0001 \mathrm{~d}$ & $27.8 \pm 2.2 \mathrm{a}$ \\
\hline As 0 M - & $0.49 \pm 0.02 \mathrm{~d}$ & $0.13 \pm 0.02 \mathrm{~d}$ & $0.0034 \pm 0.0004 \mathrm{~d}$ & $0.0014 \pm 0.0001 \mathrm{e}$ & $0.0048 \pm 0.0001 \mathrm{~d}$ & $30.2 \pm 4.6 \mathrm{a}$ \\
\hline As $12.5 \mathrm{M}+$ & $22.70 \pm 2.60 \mathrm{c}$ & $0.84 \pm 0.09 \mathrm{c}$ & $0.191 \pm 0.025 \mathrm{bc}$ & $0.0086 \pm 0.0017 \mathrm{de}$ & $0.200 \pm 0.024 \mathrm{bc}$ & $4.4 \pm 1.4 \mathrm{c}$ \\
\hline As $12.5 \mathrm{M}-$ & $15.22 \pm 0.20 \mathrm{~cd}$ & $0.99 \pm 0.06 \mathrm{c}$ & $0.092 \pm 0.008 \mathrm{~cd}$ & $0.0091 \pm 0.0002 \mathrm{~d}$ & $0.101 \pm 0.008 \mathrm{~cd}$ & $9.0 \pm 0.6 \mathrm{bc}$ \\
\hline As $25 \mathrm{M}+$ & $52.12 \pm 5.22 \mathrm{~b}$ & $3.42 \pm 0.19 \mathrm{a}$ & $0.281 \pm 0.035 b$ & $0.0387 \pm 0.0016 \mathrm{a}$ & $0.319 \pm 0.031 \mathrm{~b}$ & $12.2 \pm 0.9 \mathrm{~b}$ \\
\hline As 25 M - & $58.26 \pm 4.72 \mathrm{~b}$ & $2.10 \pm 0.12 b$ & $0.306 \pm 0.005 b$ & $0.0222 \pm 0.0005 \mathrm{c}$ & $0.328 \pm 0.014 \mathrm{~b}$ & $6.8 \pm 0.2 \mathrm{bc}$ \\
\hline As 50 M + & $91.91 \pm 8.18 \mathrm{a}$ & $3.53 \pm 0.28 \mathrm{a}$ & $0.578 \pm 0.052 \mathrm{a}$ & $0.0370 \pm 0.0006 \mathrm{ab}$ & $0.615 \pm 0.062 \mathrm{a}$ & $6.1 \pm 0.9 \mathrm{bc}$ \\
\hline As 50 M - & $100.82 \pm 10.31 \mathrm{a}$ & $3.26 \pm 0.17 \mathrm{a}$ & $0.508 \pm 0.013 \mathrm{a}$ & $0.0302 \pm 0.0029 b$ & $0.539 \pm 0.032 \mathrm{a}$ & $5.6 \pm 0.8 \mathrm{bc}$ \\
\hline As level & $p<0.0001$ & $p<0.0001$ & $p<0.0001$ & $p<0.0001$ & $p<0.0001$ & $p<0.0001$ \\
\hline AMF applic. & $p=0.4969$ & $p<0.005$ & $p=0.0824$ & $p=0.1813$ & $p<0.05$ & $p=0.7805$ \\
\hline Interaction & $p=0.2180$ & $p<0.0005$ & $p=0.1284$ & $p=0.1687$ & $p=0.1951$ & $p<0.05$ \\
\hline
\end{tabular}

Data are expressed as mean values $\pm \mathrm{SD}(\mathrm{n}=3)$ and have been analyzed by two-way analysis of variance. Mean values followed by the same letter within columns are not significantly different by Tukey's test at the $5 \%$ level. The As 0 , As 150, As 300 and As 500 refer to As concentrations of 0, 150, 300 and $500 \mu \mathrm{M} \mathrm{L}^{-1}$, while the M + and $\mathrm{M}$ - refer to the presence or absence of AMF.

non-inoculated [2.81, 2.34 and $1.14 \%$ lower in 150,300 and $500 \mu \mathrm{M}$ solutions, respectively, (Figure 2A)], the effect of AMF inoculation on the drop of initial As concentration in the contaminated hydroponic solutions by plant uptake was not statistically significant. Absence of statistic significance of AMF inoculation was also found in the Experiment II, where the final As concentrations in the 12.5 and $50 \mathrm{mg}$ $\mathrm{kg}^{-1}$ spiked soils of the AMF-inoculated vetiver plants were 2.22 and $1.54 \%$, respectively, lower than those in soils of non-inoculated plants (Figure 2B). However, evaluating the percentages of As taken up by vetiver plants from As-contaminated hydroponic solutions (Figure
3A) and As-spiked soils (Figure 3B), we found a statistical significance of AMF inoculation in both Experiment I $(p<0.05)$ and Experiment II $(p<$ $0.005)$. It is extremely interesting to note that the percentages of As taken up by vetiver plants from As-contaminated hydroponic solutions were, on average, an order of magnitude higher than those of plants grown in As-spiked soils (Figure 3A and 3B). A more efficient As uptake by vetiver grass from contaminated hydroponic solutions than spiked soils also came out by comparing the mass balance of As of Experiment I (Figure 4A) with that of Experiment II (Figure 4B). This difference in As uptake by vetiver plants from hydroponic solutions versus soils 
should be essentially due to the different phytoavailability of As in two systems. The Pineland soil used in the Experiment II is characterized by a discrete amount of Al and Fe (hydr)oxides (as suggested by the total and extractable $\mathrm{Al}$ and $\mathrm{Fe}$ values of Table 1), which are able to strongly bind As and, hence, to drastically reduce its phytoavailability in soil environments (Sarkar and Datta, 2004; Violante et al., 2010). Therefore, the phytoavailability of As in the spiked soils was in part limited by the presence of $\mathrm{Al}$ and $\mathrm{Fe}$ (hydr)oxides. phytoavailability of As in the spiked soils was in part limited by the presence of $\mathrm{Al}$ and Fe (hydr)oxides. The minimal concentration of As in play sand of each column (data not shown) and in all collected leachates (Figure 4B) also revealed a scant presence of a labile and free pool of As in the spiked soils. Similar percentages of As taken up by vetiver plants from different As-contaminated soils were also obtained by Datta et al. (2011), who found that the higher the level of $\mathrm{Al}, \mathrm{Ca}, \mathrm{Fe}$ and $\mathrm{Mg}$ content in the soil the higher the As retention capacity and, hence, the lower the As taken up by vetiver grass.

Table 5. Arsenic concentration $\left(\mathrm{mg} \mathrm{kg}^{-1}\right)$ and content $\left(\mathrm{mg} \mathrm{plant}^{-1}\right)$ in the roots and shoots of vetiver grass (Chrysopogon zizanioides L.) grown in As-spiked soils

\begin{tabular}{|c|c|c|c|c|c|c|}
\hline \multirow{3}{*}{ Treatment } & \multicolumn{2}{|c|}{ As concentration in plant tissues } & \multicolumn{3}{|c|}{ As content in plant tissues } & \multirow{3}{*}{$\begin{array}{c}\text { As content in } \\
\text { the shoots }\end{array}$} \\
\hline & Roots & Shoots & Roots & Shoots & Total biomass & \\
\hline & \multicolumn{2}{|c|}{$\left(\mathrm{mg} \mathrm{kg}^{-1}\right)$} & \multicolumn{3}{|c|}{$\left(m g\right.$ plant $\left.{ }^{-1}\right)$} & \\
\hline As 0 M + & $0.45 \pm 0.03 \mathrm{~d}$ & $0.16 \pm 0.02 \mathrm{~d}$ & $0.0043 \pm 0.0006 \mathrm{~d}$ & $0.0016 \pm 0.0001 \mathrm{e}$ & $0.0059 \pm 0.0001 \mathrm{~d}$ & $27.8 \pm 2.2 \mathrm{a}$ \\
\hline As 0 M - & $0.49 \pm 0.02 \mathrm{~d}$ & $0.13 \pm 0.02 \mathrm{~d}$ & $0.0034 \pm 0.0004 \mathrm{~d}$ & $0.0014 \pm 0.0001 \mathrm{e}$ & $0.0048 \pm 0.0001 \mathrm{~d}$ & $30.2 \pm 4.6 \mathrm{a}$ \\
\hline As $12.5 \mathrm{M}+$ & $22.70 \pm 2.60 \mathrm{c}$ & $0.84 \pm 0.09 \mathrm{c}$ & $0.191 \pm 0.025 \mathrm{bc}$ & $0.0086 \pm 0.0017 \mathrm{de}$ & $0.200 \pm 0.024 b c$ & $4.4 \pm 1.4 \mathrm{c}$ \\
\hline As $12.5 \mathrm{M}-$ & $15.22 \pm 0.20 \mathrm{~cd}$ & $0.99 \pm 0.06 \mathrm{c}$ & $0.092 \pm 0.008 \mathrm{~cd}$ & $0.0091 \pm 0.0002 \mathrm{~d}$ & $0.101 \pm 0.008 \mathrm{~cd}$ & $9.0 \pm 0.6 \mathrm{bc}$ \\
\hline As $25 \mathrm{M}+$ & $52.12 \pm 5.22 \mathrm{~b}$ & $3.42 \pm 0.19 \mathrm{a}$ & $0.281 \pm 0.035 b$ & $0.0387 \pm 0.0016 \mathrm{a}$ & $0.319 \pm 0.031 \mathrm{~b}$ & $12.2 \pm 0.9 \mathrm{~b}$ \\
\hline As 25 M - & $58.26 \pm 4.72 \mathrm{~b}$ & $2.10 \pm 0.12 \mathrm{~b}$ & $0.306 \pm 0.005 b$ & $0.0222 \pm 0.0005 \mathrm{c}$ & $0.328 \pm 0.014 \mathrm{~b}$ & $6.8 \pm 0.2 \mathrm{bc}$ \\
\hline As $50 \mathrm{M}+$ & $91.91 \pm 8.18 \mathrm{a}$ & $3.53 \pm 0.28 \mathrm{a}$ & $0.578 \pm 0.052 \mathrm{a}$ & $0.0370 \pm 0.0006 \mathrm{ab}$ & $0.615 \pm 0.062 \mathrm{a}$ & $6.1 \pm 0.9 \mathrm{bc}$ \\
\hline As 50 M - & $100.82 \pm 10.31 \mathrm{a}$ & $3.26 \pm 0.17 \mathrm{a}$ & $0.508 \pm 0.013 \mathrm{a}$ & $0.0302 \pm 0.0029 b$ & $0.539 \pm 0.032 \mathrm{a}$ & $5.6 \pm 0.8 \mathrm{bc}$ \\
\hline As level & $p<0.0001$ & $p<0.0001$ & $p<0.0001$ & $p<0.0001$ & $p<0.0001$ & $p<0.0001$ \\
\hline AMF applic. & $p=0.4969$ & $p<0.005$ & $p=0.0824$ & $p=0.1813$ & $p<0.05$ & $p=0.7805$ \\
\hline Interaction & $p=0.2180$ & $p<0.0005$ & $p=0.1284$ & $p=0.1687$ & $p=0.1951$ & $p<0.05$ \\
\hline
\end{tabular}

Data are expressed as mean values $\pm \mathrm{SD}(\mathrm{n}=3)$ and have been analyzed by two-way analysis of variance. Mean values followed by the same letter within columns are not significantly different by Tukey's test at the 5\% level. The As 0 , As 12.5, As 25 and As 50 refer to As concentrations of $0,12.5,25$ and $50 \mathrm{mg} \mathrm{kg}^{-1}$, while the M + and M- refer to the presence or absence of AMF. 

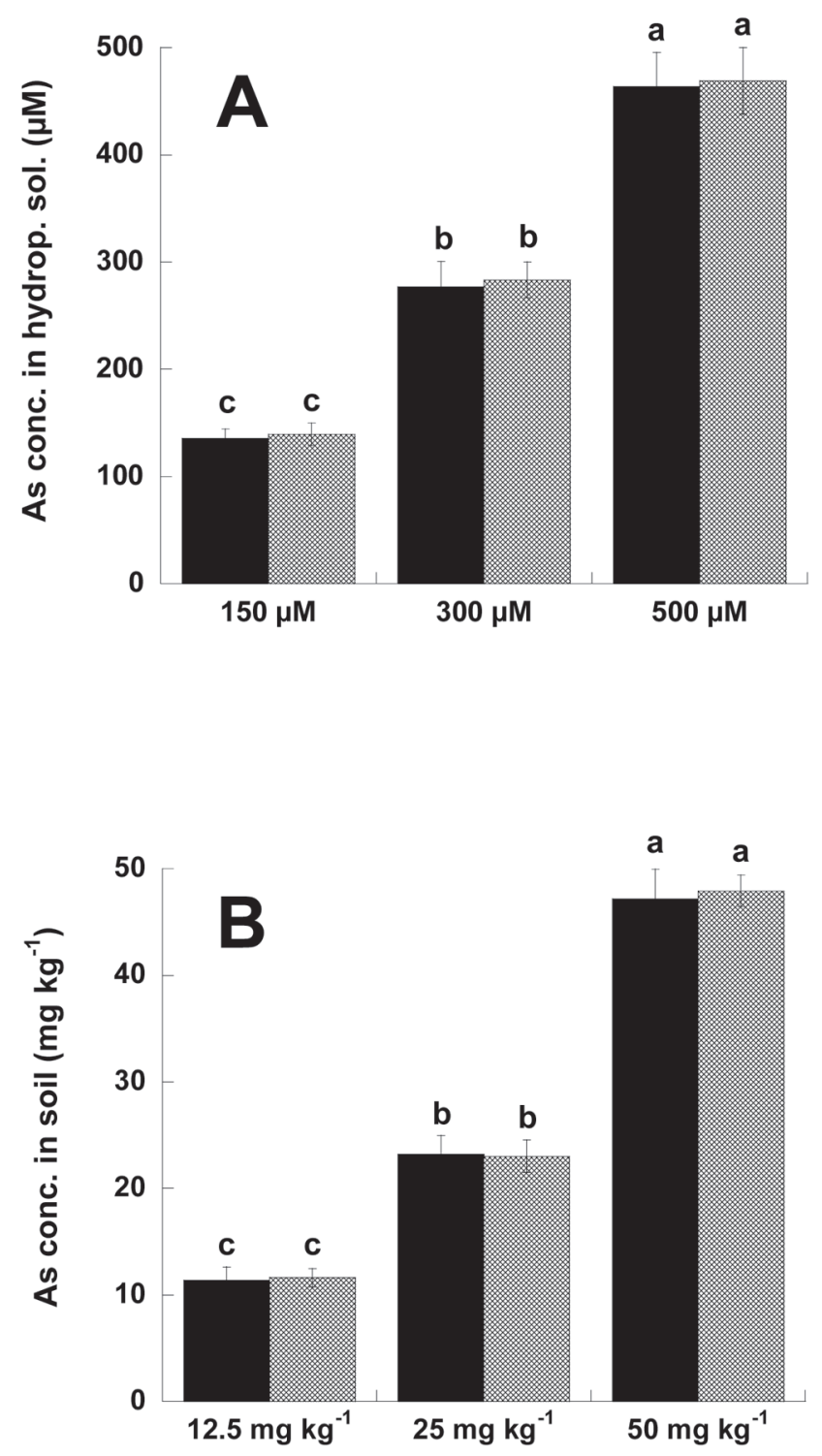

Figure 2. Arsenic concentration in the As-contaminated hydroponic solution $(\mu \mathrm{M})(\mathrm{A})$ and soil $\left(\mathrm{mg} \mathrm{kg}^{-1}\right)(\mathrm{B})$ at harvest time of Vetiver grass (Chrysopogon zizanioides L.). Black bars refer to the plants inoculated with arbuscular mycorrhizal fungi (AMF), while grid bars refer to the non-inoculated plants. Data are expressed as mean values $\pm \operatorname{SD}(n=3)$ and have been analyzed by Tukey's test at the $5 \%$ level (letters above bars). 

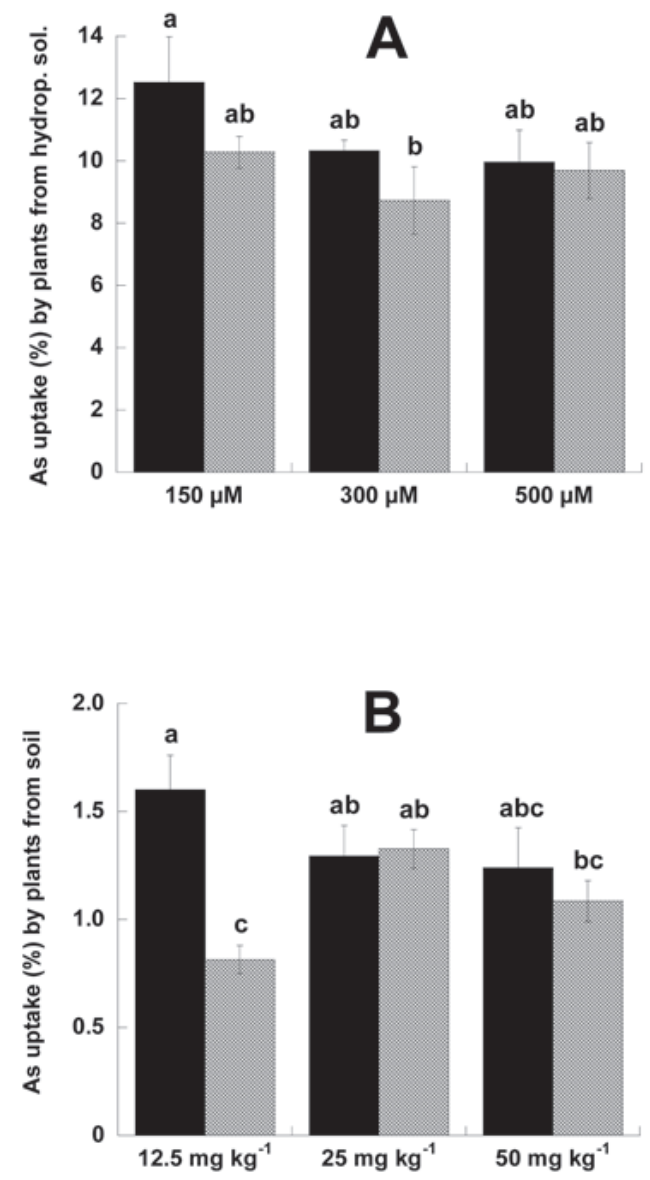

Figure 3. Arsenic uptake (\%) by Vetiver grass (Chrysopogon zizanioides L.) from As-contaminated hydroponic solution (A) and soil (B) at harvest time. Black bars refer to the plants inoculated with arbuscular mycorrhizal fungi (AMF), while grid bars refer to the non-inoculated plants. Data are expressed as mean values $\pm \operatorname{SD}(n=3)$ and have been analyzed by Tukey's test at the $5 \%$ level (letters above bars). 

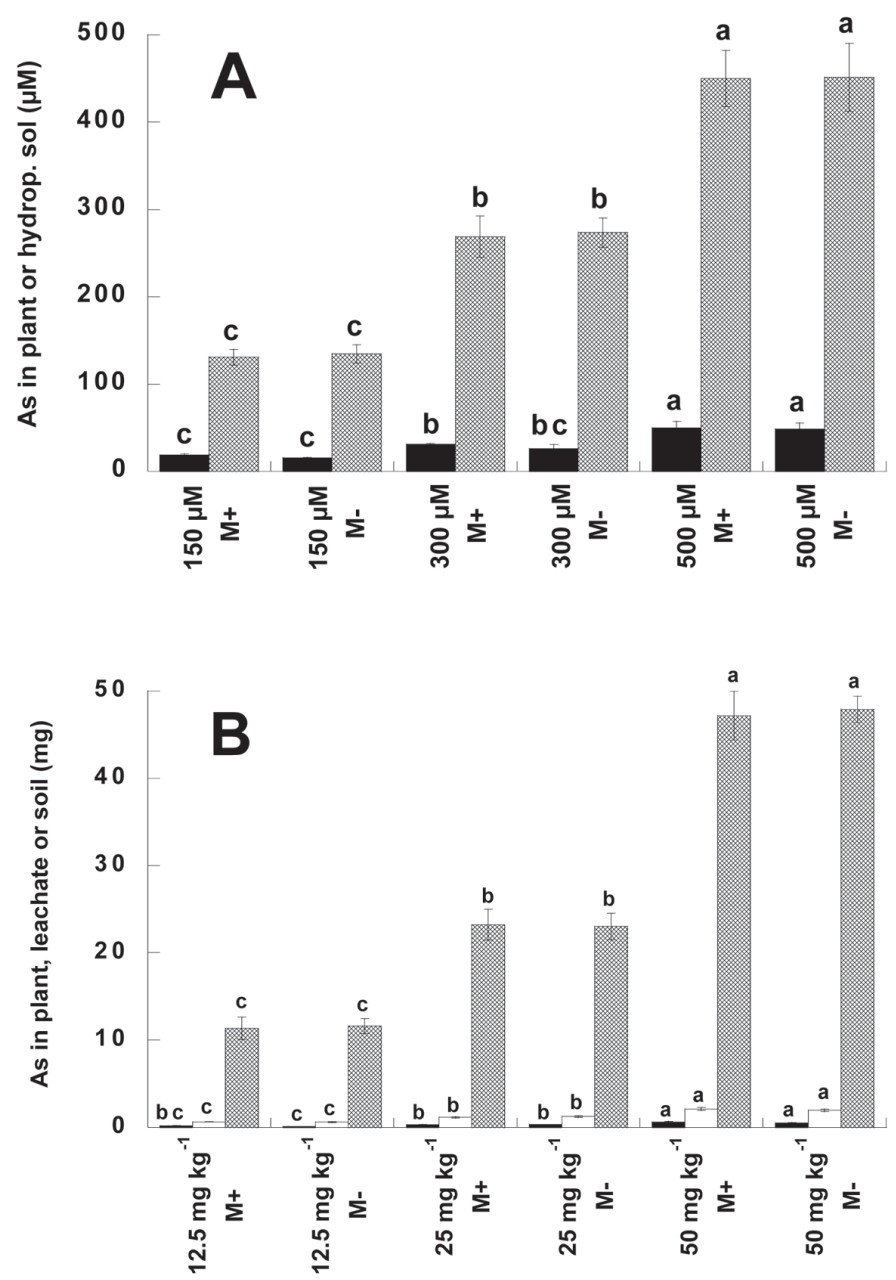

Figure 4. Mass balance of As of Experiment I (A) and Experiment II (B) at plant harvest time. Black bars (A and B) refer to As taken up by Vetiver grass (Chrysopogon zizanioides L.), white bar (B) refer to As in leachate, while grid bars (A and B) refer to As in contaminated hydroponic solution (A) and soil (B). Data are expressed as mean values $\pm \mathrm{SD}(\mathrm{n}=3)$ and have been analyzed by Tukey's test at the $5 \%$ level (letters above bars). 


\section{Conclusions}

The current study has provided useful information on the potential use of vetiver grass as pioneer plants for successful phytoremediation of Ascontaminated water and soil environments. The study highlighted an ameliorative effect of the AMF inoculation in enhancing plants growth, mainly by stimulating the development of their root system. A beneficial effect of the AMF on the As uptake by vetiver grass from contaminated hydroponic solutions and spiked soils was also found, although it was not always statistically significant $(p<0.05)$.

A more efficient As uptake by vetiver grass from contaminated hydroponic solutions than spiked soils was observed, essentially because of the higher phytoavailability in the former contaminated system. Interestingly, plants grown hydroponically also translocated higher amounts of As from their roots to the shoots. Therefore, the findings of this study reveals that the use of AMF-inoculated vetiver grass for phytoremediation purposes would be more appropriate to decontaminate As-contaminated waters when compared to soils.

\section{Acknowledgements}

Antonio G. Caporale and Antonio Violante acknowledge University of Naples Federico II for allowing them to spend time abroad at Montclair State University (Montclair, NJ, USA) for conducting the study.

\section{References}

Arnon, D. I. 1949. Copper enzymes in isolated chloroplast polyphenoloxidase in Beta vulgaris. Plant Physiol. 24, 1-15.
Bhattacharya, P., Frisbie, S. H., Smith, E., Naidu, R., Jacks, G., Sarkar, B. 2002. Arsenic in the environment: a global perspective. In: B. Sarkar (ed). Heavy metals in the environment. Marcel Dekker, New York, pp. 147-215.

Chen, HM., Zheng, C.R., Tu, C., Shen, Z. G. 2000. Chemical methods and phytoremediation of soil contaminated with heavy metals. Chemosphere. 41, 229-234.

Cozzolino, V., Pigna, M., Di Meo, V., Caporale, A.G., Violante, A. 2010. Effects of arbuscular mycorrhizal inoculation and phosphorus supply on the growth of Lactuca sativa L. and arsenic and phosphorus availability in an arsenic polluted soil under non-sterile conditions. Appl. Soil Ecol. 45, 262-268.

Dalton, P. A., Smith, R. J., Truong, P. N. V. 1996. Vetiver grass hedges for erosion control on a cropped flood plain: hedge hydraulics. Agric. Water Manag. 31, 91-104.

Datta, R., Quispe, M. A., Sarkar, D. 2011. Greenhouse study on the phytoremediation potential of vetiver grass, Chrysopogon zizanioides L., in arsenic-contaminated soils. Bull. Environ. Contam. Toxicol. 86, 124-128.

Dong, Y., Zhu, Y. G., Smith, F. A., Wang, Y., Chen, B. 2008. Arbuscular mycorrhiza enhanced arsenic resistance of both white clover (Trifolium repens L.) and ryegrass (Lolium perenne L.) plants in an arseniccontaminated soil. Environ. Pollut. 155, 174-181.

Gaur, A., Adholeya, A. 2004. Prospects of arbuscular mycorrhizal fungi in phytoremediation of heavy metal contaminated soils. Curr. Sci. 86, 528-534. 
Gonzalez-Chavez, C., Harris, P.J., Dodd, J., Meharg, A.A. 2002. Arbuscular mycorrhizal fungi enhanced arsenate resistance on Holcus lanatus. New Phytol. 155, 163-171.

Hebert, D., Outlaw Jr., R., Aghoram, W. H., Lumsden, K., Kimberly, A. S., Hampp, R. A. 1999. Visualization of mycorrhizal fungi. Tested Stud. Lab. Teach. 20, 353-355.

Leung, H.M., Ye, Z.H., Wong, M.H. 2006. Interactions of mycorrhizal fungi with Pteris vittata (As hyperaccumulator) in Ascontaminated soils. Environ. Pollut. 139, $1-8$.

Leyval, C., Joner, E. J. 2001. Bioavailability of heavy metals in the mycorrhizosphere. In: G. R. Gobran, W. W. Wenzel, E. Lombi (eds). Trace Elements in the Rhizosphere. CRC Press, Boca Raton, pp. 165-185.

Leyval, C., Turnau, K., Haselwandter, K. 1997. Effect of heavy metal pollution on mycorrhizal colonization and function: physiological, ecological and applied aspects. Mycorrhiza. 7, 139-153.

Li, X. L., Feng, G. 2001. Ecology and physiology of arbuscular mycorrhiza. Huawen Press, Beijing, China.

Liu, Y., Zhu, Y. G., Chen, B. D., Christie, P., Li, X. L. 2005. Influence of the arbuscular mycorrhizal fungus Glomus mosseae on uptake of arsenate by the As hyper accumulator fern Pteris vittata (L.). Mycorrhiza. 15, 187-192.

Marques, I.A., Anderson, L.E. 1986. Effects of arsenite, sulphite, and sulphate on photosynthetic carbon metabolism in isolated pea (Pisum sativum L., Cv. Little Marvel) chloroplasts. Plant Physiol. 82, 488-493.
Mohan, D., Pittman Jr., C.U. 2007. Arsenic removal from water/wastewater using adsorbents - A critical review. J. Hazard. Mater. 142, 1-53.

Mohan D., Pittman Jr., C.U., Bricka, M., Smith, F., Yancey, B., Mohammad, J., Steele, P. H., Alexandre-Franco, M.F., Serrano, V. G., Gong, H. 2007. Sorption of arsenic, cadmium, and lead by chars produced from fast pyrolysis of wood and bark during biooil production. J. Colloid Interface Sci. 310, 57-73.

Pang, J., Chan, G.S.Y., Zhang, J., Liang, J., Wong, M. H. 2003. Physiological aspects of vetiver grass for rehabilitation in abandoned metalliferous mine wastes. Chemosphere. 52, 1559-1570.

Pigna, M., Caporale, A.G., Cartes, P., Cozzolino, V., Mora, M., Sommella, A., Violante, A. 2014. Effects of arbuscular mycorrhizal inoculation and phosphorus fertilization on the growth of escarole (Cichorium endivia L.) in an arsenic polluted soil. J. Soil Sci. Plant Nutr. 14, 199-209.

Punamiya, P., Datta, R., Sarkar, D., Barber, S., Patel, M., Das, P. 2010. Symbiotic role of Glomus mosseae in phytoextraction of lead in vetiver grass [Chrysopogon zizanioides (L.) ]. J. Hazard. Mater. 177, 465-474.

Rausch, C., Darram, P., Brunner, S., Jansa, J., Laloi, M., Leggewie, G., Amrhein, N., Bucher, M. 2001. A phosphate transporter expressed in arbuscule-containing cells in potato. Nature. 414, 462-470.

Sarkar, D., Datta, R. 2004. Effective integration of soil chemistry and plant molecular biology in phytoremediation of metals: an overview. Environ. Geosci. 88, 53-63. 
Smith, S.E., Read, D.J. 1998. Mycorrhizal Symbiosis, Academic Press, San Diego, CA.

Smith, S.E., Smith, A.F., Jakobsen, I. 2003. Mycorrhizal fungi can dominate phosphate supply to plants irrespective of growth responses. Plant Physiol. 133, 16-20.

Srivastava, S., Shrivastava, M., Suprasanna, P., D’Souza, S. F. 2011. Phytofiltration of arsenic from simulated contaminated water using Hydrilla verticillata in field conditions. Ecol. Eng. 37, 1937-1941.

Sylvia, D.M. 1994. Vesicular-arbuscular mycorrhizal (VAM) fungi. In: R. W. Weaver, J. S. Angle, P. S. Bottomley (eds). Methods of Soil Analysis. Part 2. SSSA Book Series 5, Madison, WI, pp. 351-378.
Truong P. 2000. Vetiver grass technology for environmental protection. In: The $2^{\text {nd }}$ international. vetiver conference: Vetiver and the environment. Cha Am, Thailand.

Violante, A., Cozzolino, V., Perelomov, L., Caporale, A.G., Pigna, M. 2010. Mobility and bioavailability of heavy metals and metalloids in soil environments. J. Soil Sci. Plant Nutr. 10, 266-290.

Wong, C.C., Wu, S.C., Kuek, C., Khan, A.G., Wong, M.H. 2007. The role of mycorrhizae associated with vetiver grown in $\mathrm{Pb}-\mathrm{Zn}$ contaminated soils: greenhouse study. Restor. Ecol. 15, 60-67. 